\title{
DYRK1A wt Allele
}

National Cancer Institute

\section{Source}

National Cancer Institute. DYRK1A wt Allele. NCI Thesaurus. Code C98171.

Human DYRK1A wild-type allele is located in the vicinity of $21 \mathrm{q} 22.13$ and is approximately $148 \mathrm{~kb}$ in leng th. This allele, which encodes dual specificity tyrosine-phosphorylationregulated kinase $1 \mathrm{~A}$ protein, plays a role in the regulation of signaling pathways, protein phosphorylation and nervous system development. 